\title{
On the Indonesian Throughflow in the OCCAM 1/4 degree ocean model
}

\author{
U. W. Humphries ${ }^{1}$ and D. J. Webb ${ }^{2}$ \\ ${ }^{1}$ King Monghut's Institute of Technology, Thailand \\ ${ }^{2}$ National Oceanography Centre, Southampton SO14 3ZH, UK \\ Received: 5 March 2007 - Published in Ocean Sci. Discuss.: 21 March 2007 \\ Revised: 24 June 2008 - Accepted: 9 July 2008 - Published: 28 July 2008
}

\begin{abstract}
The Indonesian Throughflow is analysed in two runs of the OCCAM 1/4 degree global ocean model, one using monthly climatological winds and one using ECMWF analysed six-hourly winds for the period 1993 to 1998 . The long-term model throughflow agrees with observations and the value predicted by Godfrey's Island Rule. The Island Rule has some skill in predicting the annual signal each year but is poor at predicting year to year and shorter term variations in the total flow, especially in El Niño years.

The spectra of transports in individual passages show significant differences between those connecting the region to the Pacific Ocean and those connecting with the Indian Ocean. On investigation we found that changes in the northern transports were strongly correlated with changes in the position of currents in the Celebes Sea and off Halmahera. Vertical profiles of transport are in reasonable agreement with observations but the model overestimates the near surface transport through the Lombok Strait and the dense overflow from the Pacific through the Lifamatola Strait into the deep Banda Sea. In both cases the crude representation of the passages by the model appears responsible.

In the north the model shows, as expected, that the largest transport is via the Makassar Strait. However this is less than expected and instead there is significant flow via the Halmahera Sea. If Godfrey's Island Rule is correct and the throughflow is forced by the northward flow between Australia and South America, then the Halmahers Sea route should be important. It is the most southerly route around New Guinea to the Indian Ocean and there is no apparent reason why the flow should go further north in order to pass through the Makassar Strait. The model result thus raises the question of why in reality the Makassar Strait route appears to dominate the throughflow.
\end{abstract}

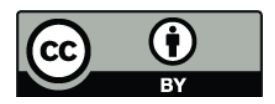

Correspondence to: D. J. Webb (david.webb@noc.soton.ac.uk)

\section{Introduction}

This paper is concerned with the ocean currents and transports between the Pacific and Indian Oceans, via the Indonesian Archipelago, making use of results from a $1 / 4^{\circ}$ version of the OCCAM global ocean model. Oceanographically the Indonesian Region is important. It connects the equatorial wave guides of the Indian and Pacific Oceans, it is the major route for water exchanges between the two oceans and, related to this, it is a major link in the thermohaline circulation of the global ocean.

The topography of the area is complex. Between the islands there are many deep basins connected by a multitude of channels with a large range of sill depths. Field measurement programmes are usually forced to concentrate on just one or two of the channels so, even when such experiments can be mounted, it is difficult to build up a full quantitative description of the flow (Godfrey, 1996; Gordon, 2005). As a result there are still major uncertainties in our estimates of the transports between the two oceans and many questions remain concerning the role of the different basins, seas and channels in these exchanges.

Under these conditions, insights that come from ocean model studies should be valuable. Ocean models are not perfect. Quantitatively they contain errors but qualitatively our experience is that the high resolution ocean models are usually good at representing the major features of the circulation. Because they represent most of the key physical processes, they can also provide useful insights into the interactions between different components of the circulation. For similar reasons they can also be extremely helpful when planning the next round of field experiments.

With these ideas in mind, in this paper we briefly review some of the results from a $1 / 4^{\circ}$ version of the OCCAM model. We report on the transports through the different channels, their variations with time and their variations with depth. Comparisons between a run using repeating monthly wind forcing and one forced by the analysed six-hourly wind

Published by Copernicus Publications on behalf of the European Geosciences Union. 
field from the 1990s, gives insight into the effect on the ocean of both short wind events and interannual variations in the wind field.

As part of the analysis we compare the model transports with those predicted by Godfrey's Island Rule (Godfrey, 1989; Wajsowicz, 1993; Godfrey, 1996). The Rule was developed to give an estimate of the mean long term transport between the Pacific and Indian Oceans. Godfrey's Rule shows good agreement with the model transports at long periods and at a period of one year. It is less good at predicting year to year variations in the transport and it also fails at short periods.

We also compare the model results with hydrographic data from the region and with the few transport measurements available from individual straits. The results highlight model weaknesses in representing narrow straits and overflows, which need to be addressed, but they also raise other questions.

\subsection{The OCCAM Model}

The OCCAM model was originally developed as part of the Ocean Circulation and Climate Advanced Modelling Project (OCCAM). It is a primitive equation model, using level surfaces in the vertical and an Arakawa-B grid in the horizontal (Arakawa, 1966). The underlying code is based on that of the Bryan, Cox and Semtner models (Bryan, 1969; Semtner, 1974; Cox, 1984; Griffies et al., 2005) but there have been a large number of changes. In particular the rigid lid surface boundary condition of the earlier codes has been replaced by a free surface. This has also meant replacing the barotropic stream function equation by a barotropic tidal equation which is solved explicitly.

The primary model variables are two tracer fields, potential temperature and salinity, the two horizontal components of velocity ${ }^{1}$, the sea-surface height and the two components of barotropic velocity. In the Arakawa B-grid, the tracer variables and sea-surface height are placed at the centre of each model grid box and the velocities are placed at the corners, an arrangement which is much better at representing small frontal regions than other standard grids. In the version of the OCCAM code used here, the model advects both tracers and momentum horizontally using the Split-Quick scheme (Webb et al., 1998a). In the vertical a revised version of the momentum advection term is also used (Webb, 1995). SplitQuick is not used in the vertical because of the increased diffusion it produces in the presence of strong internal waves - such as those generated when using realistic surface wind forcing.

Sub-grid scale horizontal mixing is represented using a Laplacian operator, with coefficients of $1 \times 10 \mathrm{~m}^{2} \mathrm{~s}^{-1}$ for diffusion and $2 \times 10 \mathrm{~m}^{2} \mathrm{~s}^{-1}$ for kinematic viscosity. In the vertical, the model uses the Pacanowski and Philander (1981)

\footnotetext{
${ }^{1}$ Vertical velocity is derived from the horizontal velocities.
}

mixing scheme for the tracer fields and vertical Laplacian mixing, with a coefficient of $1 \times 10 \mathrm{~cm}^{2} \mathrm{~s}^{-1}$, for the velocity fields. The surface fluxes of heat and fresh water are obtained by relaxing the $20 \mathrm{~m}$ thick surface layer of the model to the Levitus monthly average values (Levitus and Boyer, 1994a; Levitus et al., 1994b). The scheme uses a relaxation time scale of 30 days and linear interpolation to transform the Levitus values to the model grid. Further details about the model configuration are given in Webb et al. (1998b).

The model has a horizontal resolution of $1 / 4^{\circ} \times 1 / 4^{\circ}$ (i.e. approximately $28 \mathrm{~km}$ by $28 \mathrm{~km}$ at the equator) and has 36 levels in the vertical. The latter have thicknesses increasing from $20 \mathrm{~m}$, near the surface of the ocean, to $250 \mathrm{~m}$ at the maximum depth of $5500 \mathrm{~m}$. Note that because of the free sea surface boundary condition, the thickness of the top layer is not fixed. This is allowed for in the model equations.

The model bathymetry is derived from the DBDB5 dataset (US Naval Oceanographic Office, 1983), which provides ocean depths every $5^{\prime}$ of latitude and longitude. The depths of key sills and channels were checked manually and adjusted where necessary (Thompson, 1995) ${ }^{2}$. In the Indonesian Region, discussed here, topography is particularly important because of the sills and deep basins which block and trap different water masses. This is discussed further later in the paper.

The model is initialised with potential temperature and salinity fields derived from the Levitus (1982) annual mean dataset. The initial velocity is set to zero everywhere, as is the sea surface height.

In this paper, we analyse data from two OCCAM model runs. In the first, denoted by CMW, the model is forced with an annually repeating climatological monthly wind field. This wind field was derived by Siefridt and Barnier (1993) from the European Centre for Medium Range Weather Forecasting (ECMWF) analyses for the years 1986 to 1988. The second run, denoted by E6W, starts from the model state at the end of the eighth year of the first run. The second run is then forced with the ECMWF analysed six-hourly wind field for the period between the 1 January 1992 and the 31 December 1998.

Analysis of the model results was carried out using archive data from six years of each of the two model runs. The analysis period starts on the 1st January in the ninth year of the climatological wind run (CMW) and on the 1st January 1993 for the ECMWF analysed wind field run (E6W). During the analysis period, archive data was available at intervals of two days for the CMW run and five days for the E6W run.

\footnotetext{
${ }^{2}$ In the Arakawa B-grid, the grids for velocity variables is offset from those for tracer variables. Unfortunately although the tracer (T-point) depths were adjusted correctly, the velocity offset was not allowed for. Thus advection across some sills is only possible at much shallower depths. Table 1 , shows the advective sill depths and also the T-grid depth where diffusion can occur.
} 


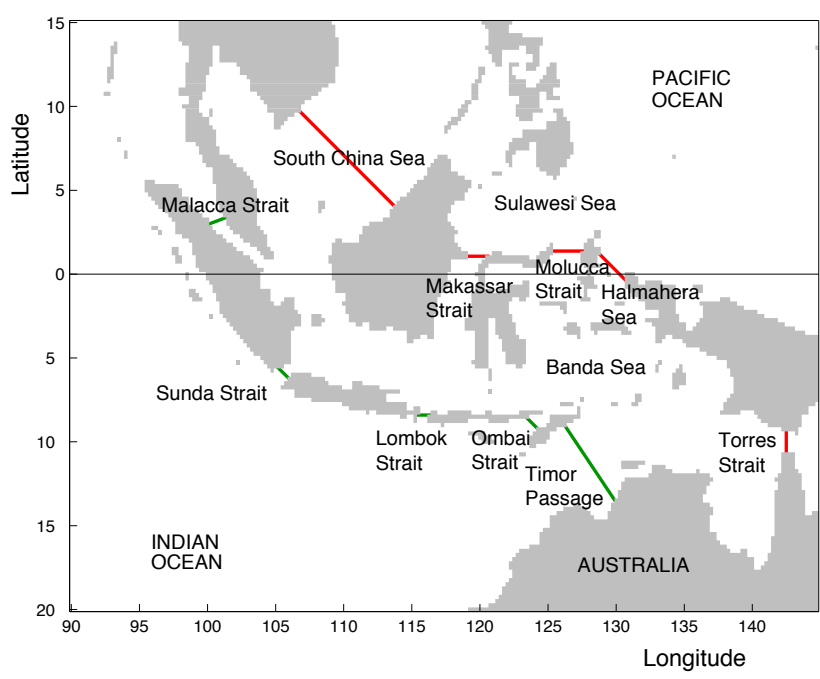

Fig. 1. The Indonesian Throughflow region. The passages of the northern section used in the paper are marked in red; those of the southern section are in green.

\section{The total volume transports}

As stated above, water from the Pacific flows through the Indonesian Archipelago into the eastern Indian Ocean via a complex series of passages (Fig. 1). In the north there are connections with the North Pacific via the shallow southern portion of the South China Sea, the Makassar Strait, the deep Molucca Sea $(1600 \mathrm{~m})$ and the Halmahera Sea. In the east there is an additional connection with the South Pacific via the shallow Torres Strait.

In the south and west, there are connections with the Indian Ocean via the Malacca and Sunda Straits, both of which are shallow, the Lombok Strait, and the deeper Ombai Strait and the Timor Passage. To investigate the flow we have therefore defined two sections, shown in Fig. 1, which stretch from Asia to Australia, and together include all of the above passages. The profiles and model sill depths of each passage are shown in Fig. 2.

Transports are calculated from the model velocity field using the equation,

$\boldsymbol{M}=\int_{z_{1}}^{h} d z \int_{A}^{B} d \boldsymbol{s} \wedge \boldsymbol{v}$

where $\boldsymbol{M}$ is the volume transport, $z$ is the vertical coordinate and $s$ the horizontal coordinate running between the two ends of the section $A$ and $B$. The vector $v$ is the velocity, $h$ is the sea surface elevation and $z_{1}$ is the ocean bottom (which is negative). In order to ensure that the result is fully consistent with the model conservation equations, the sections are chosen to follow the edges of the model tracer boxes.

Using the above equation, we calculated the ocean model transports through each passage, and the total for each sec-
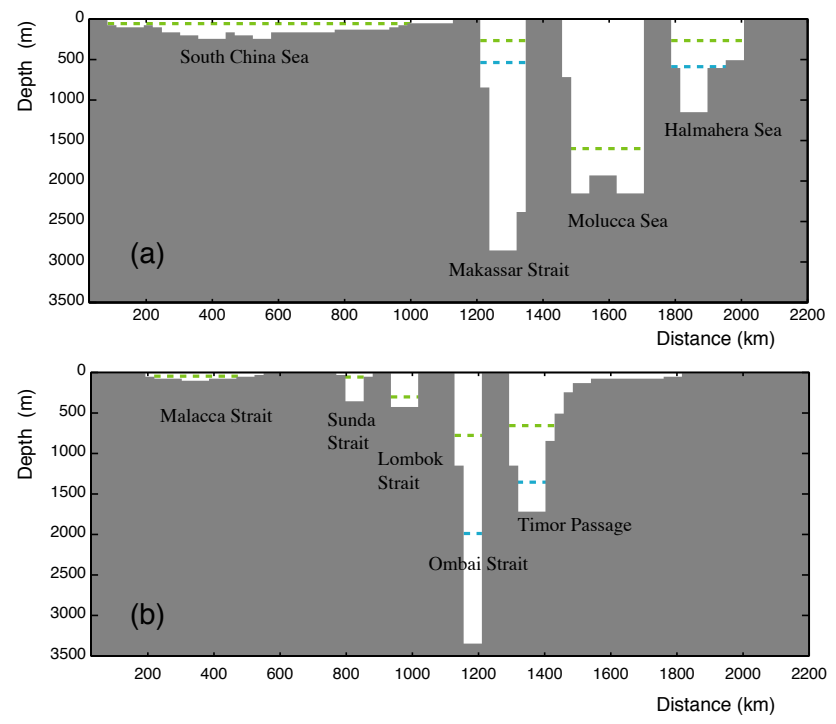

Fig. 2. Depth profiles through (a) the northern and (b) the southern sections. The sill depth of each passage in the model is shown in green. Blue indicates the sill for diffusion where this is different.

tion, over the full six year analysis period. The transport time series are plotted in Figs. 3 to 5,7 and 8 and the six year and annual averages tabulated in Tables 1 and 2 .

\subsection{Transports with climatological forcing}

When forced by the monthly climatological winds, the mean transport through the northern section during the analysis period is $11.7 \mathrm{~Sv}$. (Unless otherwise stated all transports quoted are from the Pacific towards the Indian Ocean, $1 \mathrm{~Sv}=10^{6} \mathrm{~m}^{3} \mathrm{~s}^{-1}$ ). The mean transport through the southern section is $11.8 \mathrm{~Sv}$, the slight difference being due to evaporation and precipitation in the region between the two sections. River flow was not included in OCCAM but if included it would also contribute to the difference.

The transport time series (Fig. 3a) shows that the throughflow is highly variable, with both high frequency and year to year variations. Maximum transports occur around June and July and minimum transports around December and January, the total range varying from $5 \mathrm{~Sv}$ to $6 \mathrm{~Sv}$ depending on the year. The time series also shows that transport dropped slightly during the analysis period, probably due to changing model stratification in the Indian and Pacific Oceans.

Table 1 shows that, in the north, the Makassar Strait is the primary route for the model throughflow, the average transport being $5.7 \mathrm{~Sv}$. There is also a significant annual variation (see Fig. 4) with a maximum of $8 \mathrm{~Sv}$ to $9 \mathrm{~Sv}$ occurring in July and August. Because it is the westernmost deep passage, the transport through the Makassar Strait is expected to be the largest. However the model results indicate that there are also significant transports via the Molucca Sea (2.1 Sv), 
Table 1. The transports through the northern and the southern sections. Positive transports correspond to flow from the Pacific Ocean to the Indian Ocean. $\left(1 \mathrm{~Sv}=10^{6} \mathrm{~m}^{3} \mathrm{~s}^{-1}\right)$. The sill depth is that for advective transport. Where indicated, the Arakawa B-grid allows diffusion between T-grid points at a deeper level.

\begin{tabular}{|c|c|c|c|c|c|c|}
\hline \multirow[b]{2}{*}{ Section } & \multirow[b]{2}{*}{$\begin{array}{r}\text { Width } \\
(\mathrm{km})\end{array}$} & \multirow[b]{2}{*}{$\begin{array}{r}\text { Depth } \\
(\mathrm{m})\end{array}$} & \multirow[b]{2}{*}{$\begin{array}{r}\text { Sill } \\
\text { Depth } \\
(\mathrm{m})\end{array}$} & \multirow[b]{2}{*}{$\begin{array}{l}\text { T-grid } \\
\text { Depth } \\
\text { (m) }\end{array}$} & \multicolumn{2}{|c|}{ Mean Transport (Sv) } \\
\hline & & & & & $\begin{array}{c}\text { Monthly } \\
\text { Winds } \\
\text { Years 9-14 }\end{array}$ & $\begin{array}{c}\text { ECMWF } \\
\text { Winds } \\
93-98\end{array}$ \\
\hline S. China Sea & 1,000 & 240 & 40 & & 1.7 & 1.2 \\
\hline Makassar Strait & 160 & 2,800 & 269 & $(555)$ & 5.7 & 5.9 \\
\hline Molucca Sea & 250 & 2,200 & 1,600 & & 2.1 & 1.8 \\
\hline Halmahera Sea & 230 & 1,150 & 269 & $(555)$ & 1.6 & 3.4 \\
\hline Torres Strait & 140 & 20 & 20 & & 0.6 & 0.6 \\
\hline Total & & & & & 11.6 & 12.9 \\
\hline Malacca Strait & 350 & 100 & 20 & & 0.2 & 0.1 \\
\hline Sunda Strait & 100 & 350 & 20 & & 0.3 & 0.2 \\
\hline Lombok Strait & 80 & 430 & 389 & & 5.7 & 5.6 \\
\hline Ombai Strait & 80 & 3,400 & 779 & (1068) & 4.5 & 4.9 \\
\hline Timor Passage & 520 & 1,800 & 659 & (1419) & 1.1 & 2.2 \\
\hline Total & & & & & 11.7 & 13.0 \\
\hline
\end{tabular}

Table 2. Average transports for each strait and for each year when the model is forced by analysed ECMWF winds. Positive transports correspond to flow from the Pacific Ocean to the Indian Ocean. Transports in Sverdrups $\left(1 \mathrm{~Sv}=10^{6} \mathrm{~m}^{3} \mathrm{~s}^{-1}\right)$.

\begin{tabular}{lccccccc}
\hline YEAR & 1993 & 1994 & 1995 & 1996 & 1997 & 1998 & $1993-1998$ \\
\hline S. China Sea & 1.5 & 1.5 & 1.2 & 0.8 & 1.2 & 0.9 & 1.2 \\
Makassar Strait & 5.4 & 6.0 & 6.3 & 7.2 & 5.0 & 5.5 & 5.9 \\
Molucca Sea & 2.1 & 0.8 & 1.9 & 1.4 & 0.2 & 4.4 & 1.8 \\
Halmahera Sea & 1.9 & 5.9 & 5.0 & 4.9 & 3.2 & -0.4 & 3.4 \\
Torres Strait & 0.75 & 0.67 & 0.43 & 0.43 & 0.66 & 0.56 & 0.58 \\
\hline Total & 11.7 & 14.9 & 14.9 & 14.7 & 10.2 & 10.9 & 12.9 \\
\hline Malacca Strait & 0.16 & 0.19 & 0.12 & 0.09 & 0.18 & 0.06 & 0.13 \\
Sunda Strait & 0.24 & 0.29 & 0.18 & 0.15 & 0.28 & 0.11 & 0.21 \\
Lombok Strait & 5.4 & 6.7 & 6.1 & 7.2 & 4.8 & 3.4 & 5.6 \\
Ombai Strait & 4.8 & 5.2 & 5.9 & 4.9 & 3.3 & 5.1 & 4.9 \\
Timor Passage & 1.2 & 2.6 & 2.7 & 2.5 & 1.8 & 2.2 & 2.2 \\
\hline Total & 11.8 & 15.0 & 15.0 & 14.8 & 10.3 & 10.9 & 13.0 \\
\hline
\end{tabular}

the Halmahera Sea $(1.6 \mathrm{~Sv})$, and the shallow South China Sea $(1.7 \mathrm{~Sv})$.

The transport time series (Fig. 4) also show a wide range of behaviour. In the South China Sea, the transport follows a regular pattern, repeating each year with a maximum flow of $4 \mathrm{~Sv}$ to the south in January and a small, $\sim 0.2 \mathrm{~Sv}$, northward flow in June. When Fourier transformed, the data shows an r.m.s. amplitude ${ }^{3}$ of $1.6 \mathrm{~Sv}$ near 1 cy/year. There are additional contributions at 2 and $4 \mathrm{cy} /$ year resulting from the underlying saw-tooth signal.

\footnotetext{
${ }^{3}$ Quoted r.m.s. values are the square root of the total variance in neighbouring frequency bands
}

The South China Sea route is very shallow, many regions having depths of less than $40 \mathrm{~m}$, so the effect of bottom friction can be significant. In summer sea levels remain relatively constant throughout the region and currents are weak. As an example the sea level difference between the Gulf of Thailand $(10 \mathrm{~N}, 101 \mathrm{E})$ and the Java Sea $(6 \mathrm{~S}, 110 \mathrm{E})$ is only $3 \mathrm{~cm}$ (July of year 9). In winter much higher sea levels are found in the Gulf of Thailand and adjacent regions, the sea level difference increasing to $40 \mathrm{~cm}$ (January of year 9) under the influence of the north-east monsoon.

At this time sea level drops $20 \mathrm{~cm}$ along the Malasian Coast, where there is a narrow boundary current, and it 

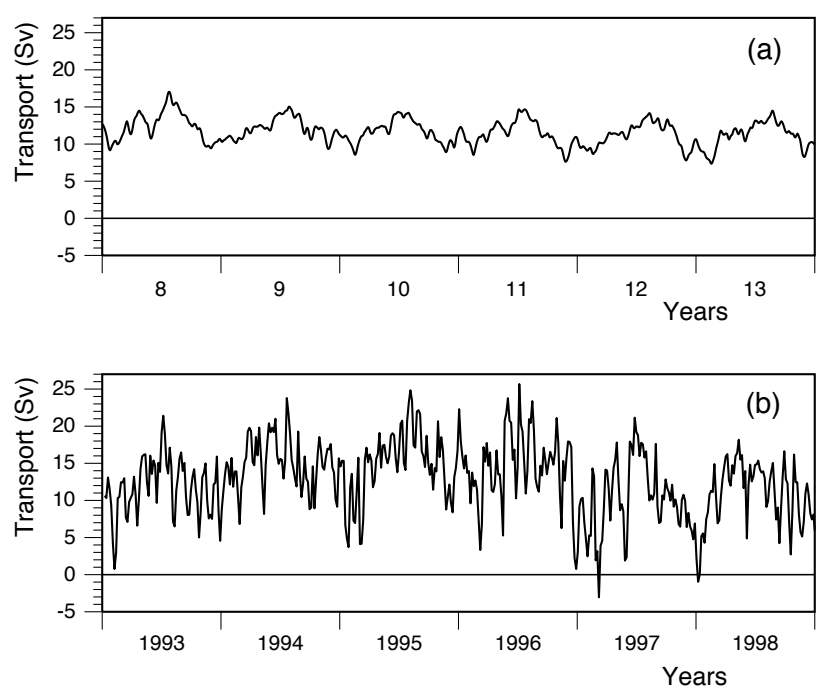

Fig. 3. Total transport from the model when using (a) monthly climatological winds and (b) ECMWF analysed six-hourly winds. Positive values correspond to a net flow from the Pacific to the Indian Ocean. The figure shows the transports through the northern section. The transports through the southern section are similar.

drops a further $20 \mathrm{~cm}$ at the Karimata Strait (Selat Karimata: $2 \mathrm{~S}, 109 \mathrm{E}$ ) where there is another region of strong currents through the deepest channel. In both cases the along-stream pressure gradient in the model is balanced primarily by the bottom friction term. From these results we conclude that the strong repeating annual signal seen in the model is a result of the balance between sea level changes produced by the monsoons and bottom friction opposing the resulting currents. A similar behaviour is also seen in the transport through Torres Strait, the small annual signal reflecting the fact that the strait is both narrow and shallow.

A more complicated pattern is seen in the three deep sections. Here the regular annual signal is still present but it is largely masked by an irregular fluctuations with periods near 6 cy/year. If the six-year Makassar Strait time series is Fourier transformed, the spectra shows a peak with r.m.s. amplitude of $0.9 \mathrm{~Sv}$ at $1 \mathrm{cy} / \mathrm{year}$, a similar peak with r.m.s. amplitude also of $0.9 \mathrm{~Sv}$ at 2 cy/year, and then a large group of lines with variances of order $0.5 \mathrm{~Sv}$ between 5 and 7 cy/year. The spectra for the Halmahera and Molucca passages, show annual (and for Halmahera a semi-annual peak) of comparable amplitudes but the peaks around 6 cy/year are much larger, 1.1 Sv for Halmahera and 1.3 Sv for Molucca.

As discussed by Qu et al. (2005) and Tozuka et al. (2007), part of the reduced winter transport in the Makassar Strait is due to the increased Karimata Strait transport. In the climatological run this reached $4 \mathrm{~Sv}$ in winter, of which just over $1 \mathrm{~Sv}$ turned northwards into the Makassar Strait, for a time reversing the mean flow there in the top $60 \mathrm{~m}$ (as discussed
Transport

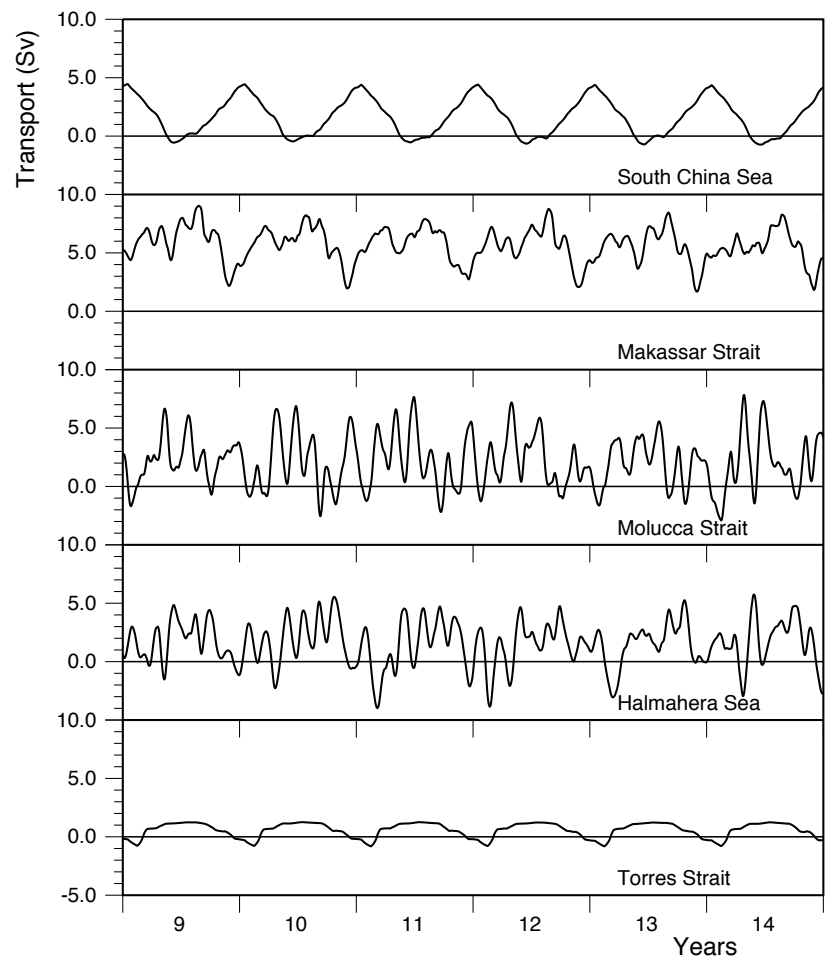

Fig. 4. Transport time series for passages in the northern section when the model is forced with monthly climatological winds.

later, the annual average flow in the Makassar Strait is southwards at all depths).

Amongst the Southern sections (Fig. 5), the largest mean transports in the model occur through the Lombok Strait $(5.7 \mathrm{~Sv})$ and the deeper Ombai Strait $(4.5 \mathrm{~Sv})$. The fluctuations in the transport through the Lombok Strait are dominated by a two cycle per year signal (amplitude $1.2 \mathrm{~Sv}$ ). In the Ombai and Timor passages there are strong annual and semi-annual signals, Timor having spectral peaks of $1.1 \mathrm{~Sv}$ at $1 \mathrm{cy} /$ year and $0.9 \mathrm{~Sv}$ at $2 \mathrm{cy} / \mathrm{year}$ and Ombai peaks of $0.8 \mathrm{~Sv}$ at $1 \mathrm{cy} / \mathrm{year}$ and $0.6 \mathrm{~Sv}$ at $2 \mathrm{cy} / \mathrm{year}$. All three passages also show irregular fluctuations at shorter periods but the amplitude is much smaller than for the northern sections. Thus for Lombok Strait the fluctuations near 6 cy/year have an r.m.s amplitude of $0.5 \mathrm{~Sv}$ and Ombai and Timor Straits both have values near $0.3 \mathrm{~Sv}$.

\subsection{The source of variability}

The fact that the fluctuations with periods near 6 cpy are irregular implies that they are not due to the local repeating winds. We investigated the source of the variability by fourier transforming the model SSH and barotropic velocity 


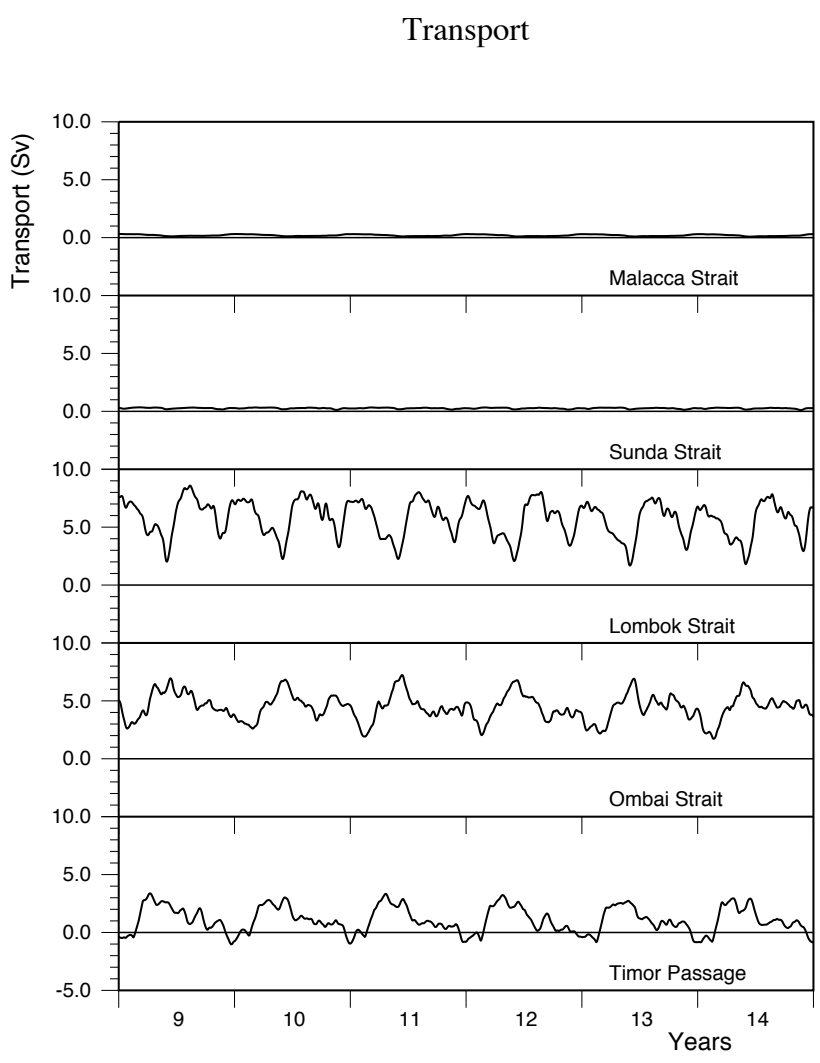

Fig. 5. Transport time series for passages in the southern section when the model is forced with monthly climatological winds.

fields and comparing the properties near 6 cpy with those at other periods.

Figure 6 shows the variance of the barotropic transport near 6 cpy. The largest values are found south-east of Mindanao in the region normally associated with the Mindanao Eddy (or more accurately the Mindinao Retroflection). This is also a region of large SSH variance and where the fourier components indicate that the features are propagating. Similar behaviour is also found in the Celebes Sea where the model shows eddies spawned by the retroflection region.

Correlations of the northern strait transport time series with the sea surface height and velocity fields show connections between the strait transports and the Mindinao Eddy region, but the correlation values (up to 0.55 ) are only just above the large background value (typically 0.3 ). This may be because such a correlation includes all frequencies. The high background value may also be a result of the regular forcing of the ocean during this run of the model.

However a study of periods when the transport time series was changing rapidly, showed that the Molucca Sea transport fell when the Mindinao Eddy moved furthest south, such that the retroflecting current swept past the northern entrance to the Molucca Sea. The Makassar transport also dropped when the eddy in the Celebes Sea moved to a similar posi-

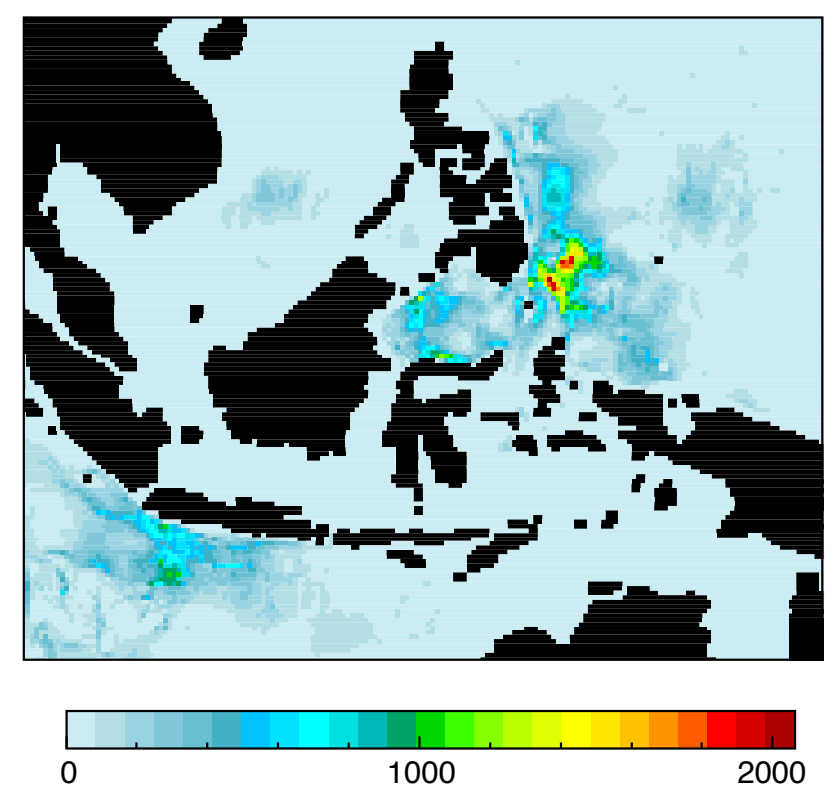

Fig. 6. Variance of barotropic transport near six cycles per year. (Units are $\mathrm{m}^{4} \mathrm{~s}^{-2}$, i.e. $\left.\left(\mathrm{m}^{3} \mathrm{~s}^{-1} \text { per meter }\right)^{2}\right)$

tion just north of the Makassar Strait. (The Makassar Eddy also tended to be further south than normal at such times.) From these results we conclude that the 6 cy/year fluctuations in transport arises, because first, there is some relatively periodic behaviour of the eddies during this run of the model, and because secondly, the Mindinao and Celebes Sea eddies can have a significant effect on the transport though the different straits.

\subsection{Transports with high-frequency forcing}

In the second run, when the model is forced by the more realistic ECMWF analysed winds, there are significant changes in both the mean transports and their variability. The total mean throughflow, averaged over the six years, increases from 11.7 and $11.8 \mathrm{~Sv}$ to $12.9 \mathrm{~Sv}$ and $13.0 \mathrm{~Sv}$ through the northern and southern sections respectively. The time series (Fig. 3b and Table 2), shows that the largest values of the throughflow occurred between 1994 and 1996, the annual average reaching $14.9 \mathrm{~Sv}$ through the northern section in both 1994 and 1995 . This is followed by a sharp drop to $10.2 \mathrm{~Sv}$ in 1997 and $10.9 \mathrm{~Sv}$ 1998. Both years were partly affected by an El Niño. The SOI index was large and negative between April 1997 and April 1998, but the model indicates that the throughflow was reduced over a much longer period of time.

In the north, the Makassar Strait is the primary route for the throughflow with a mean transport over the six year period of $5.9 \mathrm{~Sv}$. The maximum flows, up to $10 \mathrm{~Sv}$, occur in July and August and the minimum, as low as $2 \mathrm{~Sv}$, in January and February. 


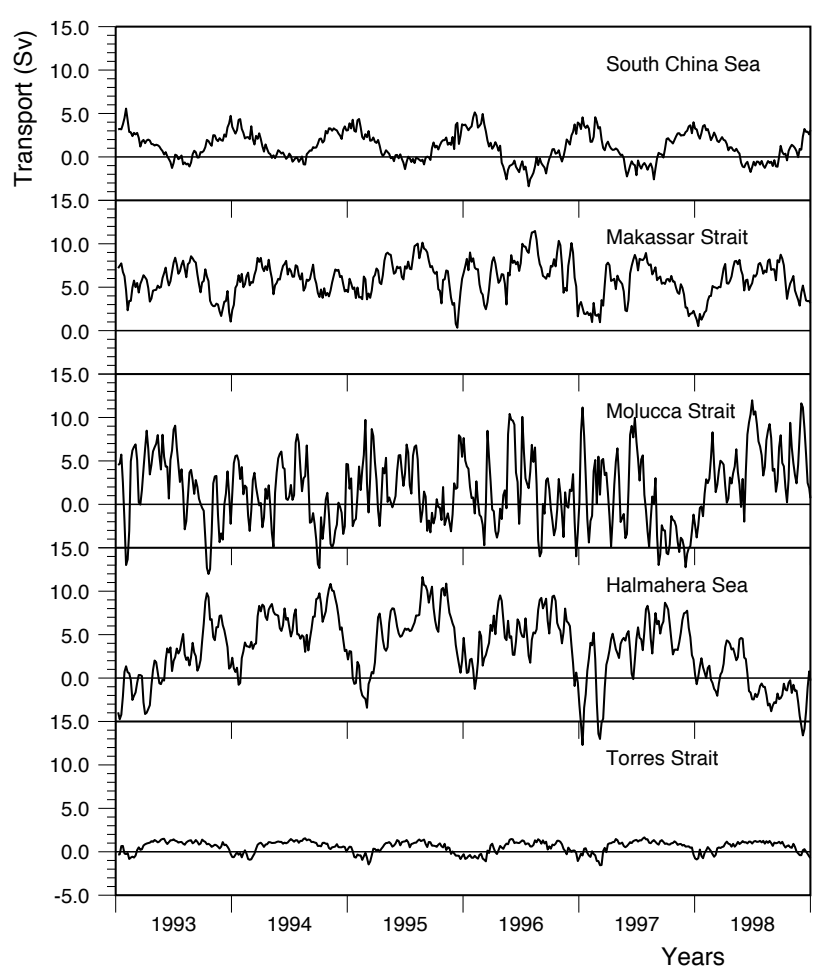

Fig. 7. Transport time series for passages in the northern section when the model is forced with ECMWF analysed six-hourly winds.

The next most important route in the model is via the Halmahera Sea, where the mean transport is $3.4 \mathrm{~Sv}$. This is $1.8 \mathrm{~Sv}$ more than that found with monthly averaged winds. Maximum southward flows, around $6 \mathrm{~Sv}$, occur in October and November during the Northwest Monsoon. Minimum flows can in practice be northward flows, the northward transport during January and February 1997 averaging 2 Sv. There are also significant transports via the shallow South China Sea (average of $1.2 \mathrm{~Sv}$ ) and the Molucca Sea $(1.8 \mathrm{~Sv})$. Year to year variability is significant (Table. 2), the Halmahera Sea transport ranging from $5.9 \mathrm{~Sv}$ in 1994 to $-0.44 \mathrm{~Sv}$ (i.e. northwards) in 1998.

There is also a large increase in variability at shorter periods although the annual signal (Fig. 3) still appears coupled to the monsoon. Between 1993 and 1996 maximum maximum monthly values, up to $21 \mathrm{~Sv}$, occur in June, July and August and minimum values around $10 \mathrm{~Sv}$ in December and January. The El Niño years of 1997 and 1998 have lower transports, the monthly average throughflow being below $5 \mathrm{~Sv}$ in January 1998.

Amongst the northern sections, the largest amount of short term variability is found in the Molucca Sea. The Makassar and Halmahera passages also show significant variability but in the two shallow sections, the South China Sea and Torres Strait, short term variability is small.

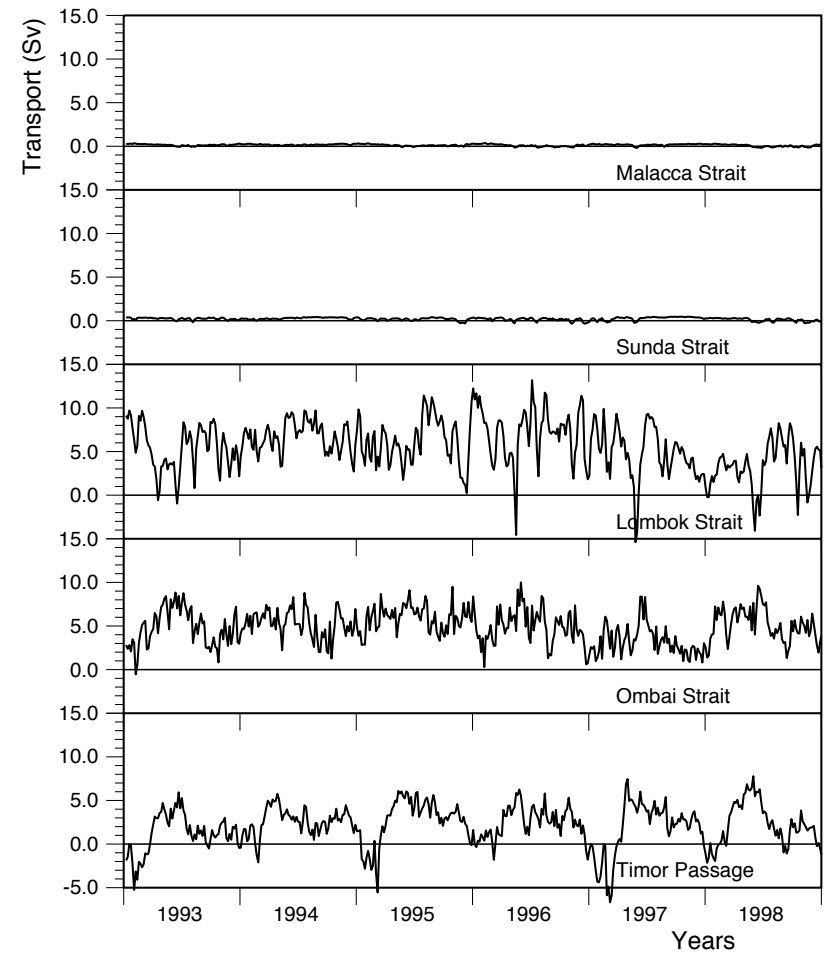

Fig. 8. Transport time series for passages in the southern section when the model is forced with ECMWF analysed six-hourly winds.

Amongst the southern sections, the largest mean transports occur through the Lombok Strait $(5.6 \mathrm{~Sv})$ and the Ombai Strait (4.9 Sv). Next most important is the Timor Passage, its average transport, $(2.2 \mathrm{~Sv})$, being almost twice that found with the monthly wind forcing run. All three passages also show significant short term variability, but the amplitude is less than that seen in the deep northern passages.

\section{Vertical structure}

The vertical distribution of transport was calculated from the OCCAM model velocity field using the equation,

$T_{1}=\int_{A_{1}}^{B_{1}} d \boldsymbol{s} \wedge \boldsymbol{u}_{\mathbf{1}}\left(\delta z_{1}+h_{0}\right) / \delta z_{1}$,

for the shallowest model level, and,

$T_{i}=\int_{A_{i}}^{B_{i}} d \boldsymbol{s} \wedge \boldsymbol{u}_{i}$

for the deeper levels, where $T_{i}$ is the transport per unit depth at level $i, \boldsymbol{u}_{\boldsymbol{i}}$ the mean velocity, $\delta z_{i}$ the level thickness, $h_{0}$ the sea surface elevation and $s$ is the horizontal coordinate along the section. The resulting vertical distribution of the mean (six-year average) transports are show in Figs. 9 to 12. 


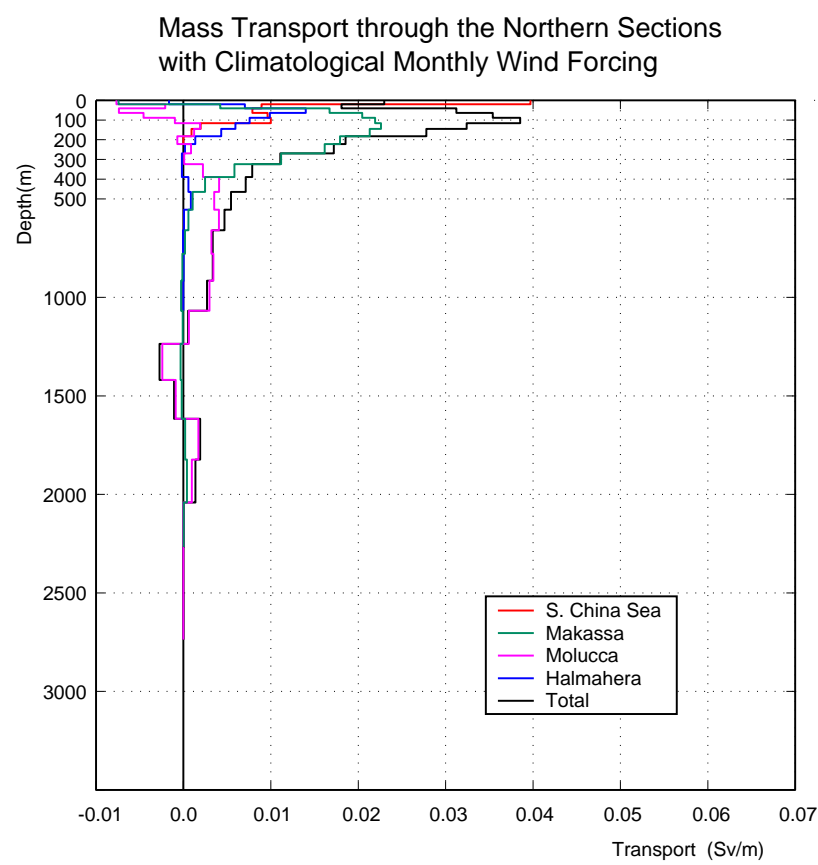

Fig. 9. Vertical profile of mean transports through the northern section when forced by monthly climatological winds (average of years 8 to 13 inclusive).

\subsection{Monthly climatological wind run}

The total transports per unit depth for the northern section of the monthly climatology wind forced run is shown in Fig. 9 together with the transport through the individual passages. The total transport is concentrated mainly in the top $500 \mathrm{~m}$ and it has a sub-surface maxima at approximately $100 \mathrm{~m}$ depth. Below $500 \mathrm{~m}$ the transport per unit depth remains fairly uniform down to $1100 \mathrm{~m}$. There is then a weak flow reversal, down to $1700 \mathrm{~m}$, followed by a weak flow out of the Pacific down to $2000 \mathrm{~m}$.

The data for the individual passages shows that the most of the flow above $400 \mathrm{~m}$ is through the Makassar Strait. This has a sub-surface maximum (around $120 \mathrm{~m}$ ) and then drops off rapidly, with little flow below $400 \mathrm{~m}$ and none below $600 \mathrm{~m}$. Below $400 \mathrm{~m}$, largest transports are found through the Molucca Sea, and this is responsible for all of the transports below $600 \mathrm{~m}$. This is to be expected as it is the only passage with a sill below $550 \mathrm{~m}$. Above $500 \mathrm{~m}$ the flows through the Molucca Sea are negligible, except for a slight flow reversal in the top $100 \mathrm{~m}$.

Near the surface the flows through other sections in the north also become significant. In the case of the South China Sea, this may be expected because of the effect of the monsoon on the shallow waters of the region. The beta effect may also be involved, steering any steady current from the North Pacific into the Indian Ocean as far west as possible.

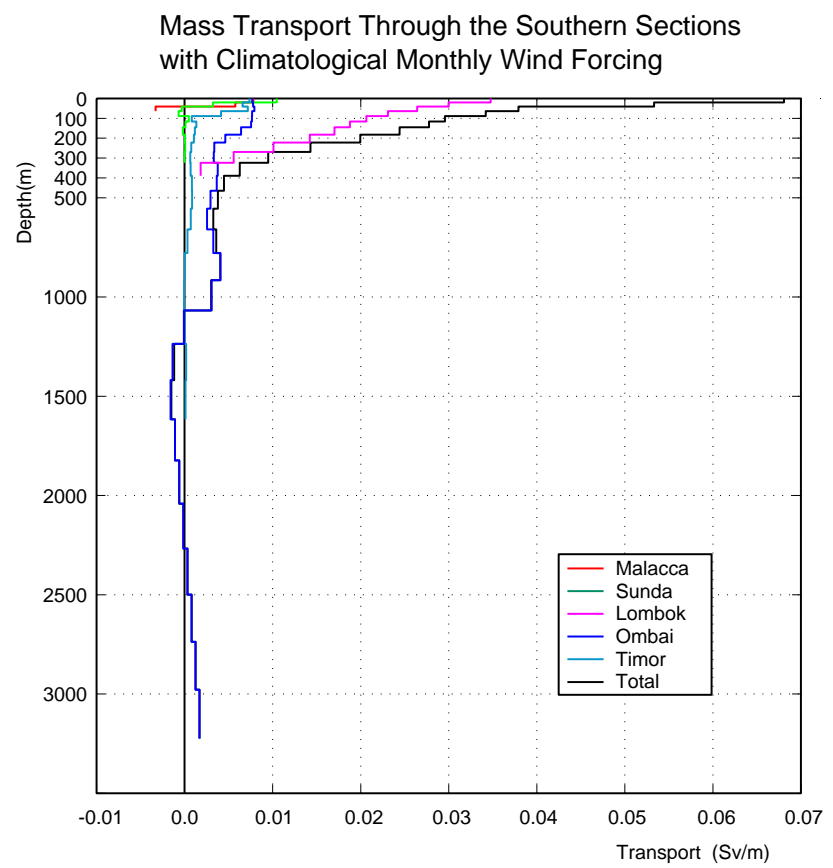

Fig. 10. Vertical profile of mean transports through the southern section when forced by monthly climatological winds (average of years 8 to 13 inclusive).

However the model also shows significant flow through the Halmahera Sea. This extends down to at least $200 \mathrm{~m}$, is unexpected, and indicates that other factors are involved.

The corresponding transports for the southern sections are shown in Fig. 10. The total transport shows two important changes. First the sub-surface maximum has disappeared and instead the maximum transport per unit depth occurs at the surface. Secondly there is a weak deep circulation, with flow out of the Indian Ocean between $1200 \mathrm{~m}$ and $2100 \mathrm{~m}$ and a return flow below that down to $3200 \mathrm{~m}$.

Above $300 \mathrm{~m}$ the bulk of the flow is through the Lombok Strait. (This is a fault of the model which is discussed later). The flow has a maximum at the surface and then drops off rapidly with depth. Next in importance is the Ombai Strait. This has a slight near surface maximum, but otherwise the flow is relatively constant down to $1100 \mathrm{~m}$. Below $300 \mathrm{~m}$ almost all the transport goes via this route. It is also responsible for all of the weak deep circulation below $1200 \mathrm{~m}$.

\subsection{High frequency forcing}

The vertical distribution of transport with actual six-hourly wind forcing is shown in Fig. 11 and 12. The gross features are the same as for monthly forcing - except for the surface layer where there are significantly increased transports through the Halmahera Strait in the north and through the Ombai and Timor Straits in the south. The six-hourly 


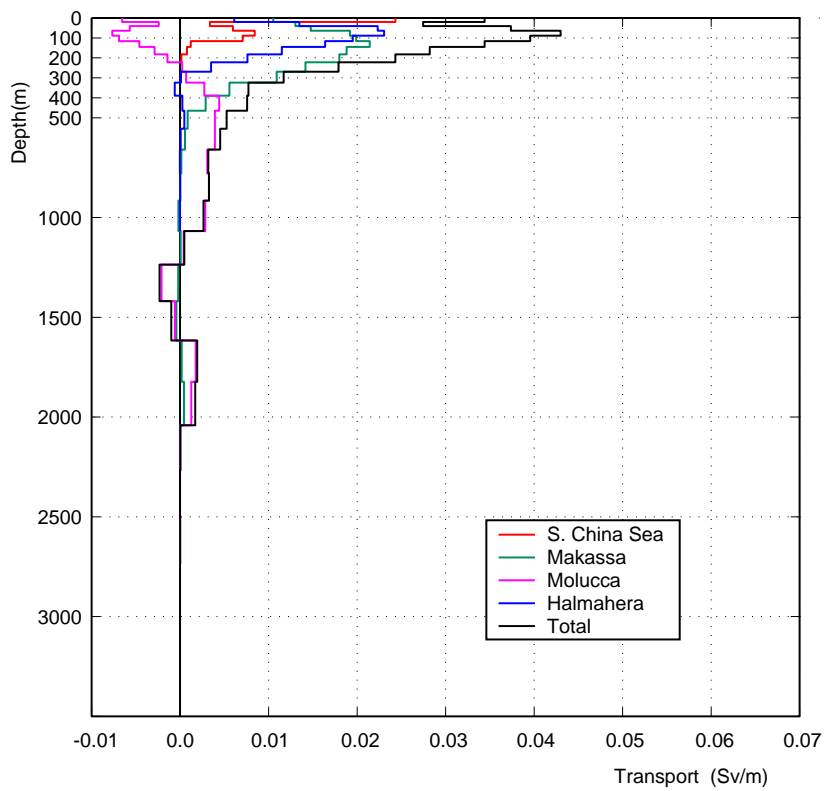

Fig. 11. Vertical profile of mean transports through the northern section when forced by six-hourly winds (average of years 1993 to 1998 inclusive).

wind run also produces a reduction of the deep flows through the Ombai Strait.

It is not obvious why the vertical profiles differ in the two runs. The monthly climatological run was based on winds for the period 1986-1988, whereas the analysis period for the actual six-hourly wind run covers the period 1993-1998. Thus the differences in the mean winds over these periods may be responsible. However the actual winds may vary very rapidly, so it is possible that non-linearities acting on the short term wind driven fluctuations may also produce the observed changes in the averaged current.

\section{Godfrey's Island Rule}

In his study of the Global Ocean Circulation, Godfrey (1989, 1996) developed a new method for estimating the average total northward transport of the South Pacific Ocean between Australia and South America. The method involves an integral of the time average wind stress along a path which includes two east-west crossings of the South Pacific, at the northern and southern extremities of the Australian and New Guinea continental shelf. These two east-west sections are then joined by paths along the shelf edges of South America and West Australia.

Godfrey's estimate of the transport, which has become known as Godfrey's Island Rule, is given by the equation:

$T_{o}=\oint \boldsymbol{\tau} \cdot d \boldsymbol{s} / \rho_{o}\left(f_{N}-f_{S}\right)$,

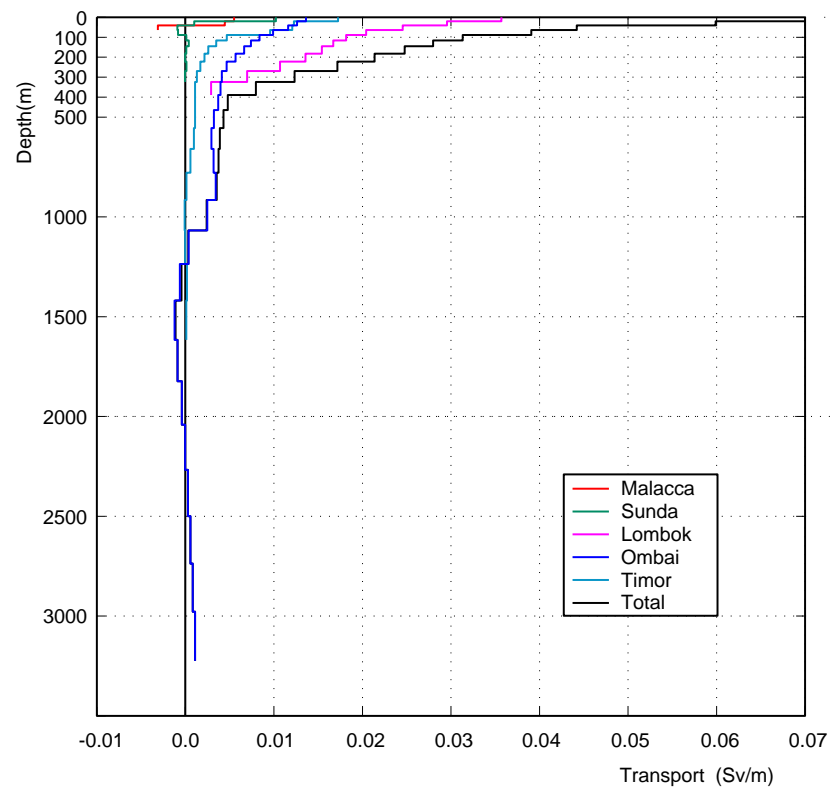

Fig. 12. Vertical profile of mean transports through the southern section when forced by ECMWF six-hourly winds (average of years 1993 to 1998 inclusive).

where $T_{o}$ is the total depth-integrated mass transport, $\boldsymbol{\tau}$ is the time average wind stress, $s$ is the locus of the path of integration, $\rho_{o}$ is the mean water density, and $f_{N}-f_{S}$ are the values of the Coriolis parameter at the latitudes of the two east-west crossings.

If the Island Rule is valid then it should equal the Indonesian Throughflow plus any transport through the Bering Strait and the effect of evaporation, precipitation and river inflow in the North Pacific. In practice the mean northward transport through the Bering Strait is about $1 \mathrm{~Sv}$ and precipitation, evaporation and river inflow also contribute about $1 \mathrm{~Sv}$. In the following we assume that these terms cancel out.

Pirani (1999) used results from the climatological wind run to carry out a preliminary comparison of the model throughflow with the value predicted by Godfrey's Island Rule. The integral path was approximated by a rectangle with boundaries at the equator, $115^{\circ} \mathrm{E}, 40^{\circ} \mathrm{S}$ and $85^{\circ} \mathrm{W}$ and comparisons were made for model years nine to twelve inclusive of the run. Godfrey's Rule is based on Sverdrup transport ideas, which are really concerned with the long term mean transport of the ocean after all transient waves have died out. However Pirani's results showed that there was good agreement for both the mean transport each year and the annual cycle. This implies that there may be more to be gained from the integral, for example as an analogue of the time varying Indonesian Throughflow.

For the present study we calculated the integral in (4) using the more accurate path shown in Fig. 13. The path is similar to the one used by Godfrey but, to the west of Australia 


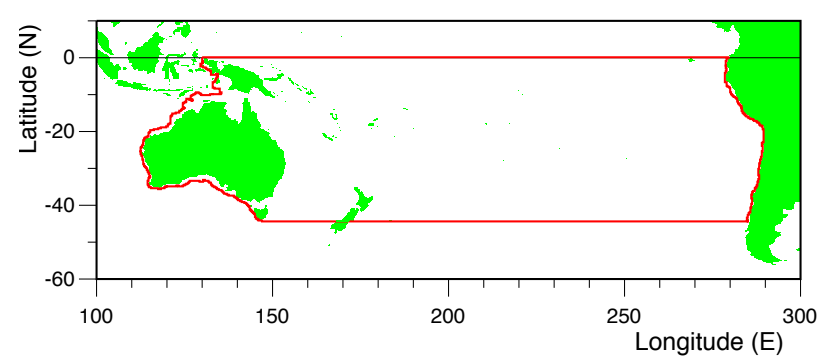

Fig. 13. Path, in red, used for the Godfrey Integral of the wind stress.

and South America, it follows the continental shelf edge at a depth of $100 \mathrm{~m}$. No correction has been made for New Zealand as Godfrey found that its effect was negligible.

Comparisons were made for years nine to fourteen for run CMW and years 1993 to 1998 for run E6W. For each year we calculated the mean transports and the amplitude of the annual, semi annual and higher frequency signals. The results are given in Tables 3 and 4, together with the response, that is the ratio of the actual transport to the value predicted by the Island Rule and the phase delay between the maximum in the wind forcing and the maximum in the transport.

The results from the climatological forcing run agree with those of Pirani. The mean value of the throughflow each year is given to a good approximation by the Godfrey Island rule. The annual signal, which can be seen in Fig. 3, is also in good agreement for both the amplitude and phase. At higher frequencies the agreement is poor, the actual variation being much smaller than the value predicted by the Godfrey formula.

With the six-hourly winds there is much more variability in both the observed transports and the Godfrey predicted value. Averaged over the six years, the model throughflow agrees well with the Godfrey prediction. However in individual years (Table 4), both the mean transports and the ratio vary significantly, indicating that the Island Rule by itself is not suitable as an analogue of the annual mean transports.

Figure 3 indicates that the annual signal is larger in the sixhourly run than in the climatological run, but its peak occurs at about the same time during the year. This is confirmed by Fourier analysis (see Table 4) which also shows that the Godfrey Island Rule has some skill in predicting the amplitude and phase of the transport especially between 1993 and 1996.

Smoothed versions of the two timeseries (Fig. 14) also show better agreement between between 1993 and 1996 than for the two El Niño years, 1997 and 1998. The Island Rule is based on the steady state solution after all gravity and Rossby waves have propagated around the system and died away. The present results thus indicate that the energetic waves generated by the El Niño may take longer to propa-

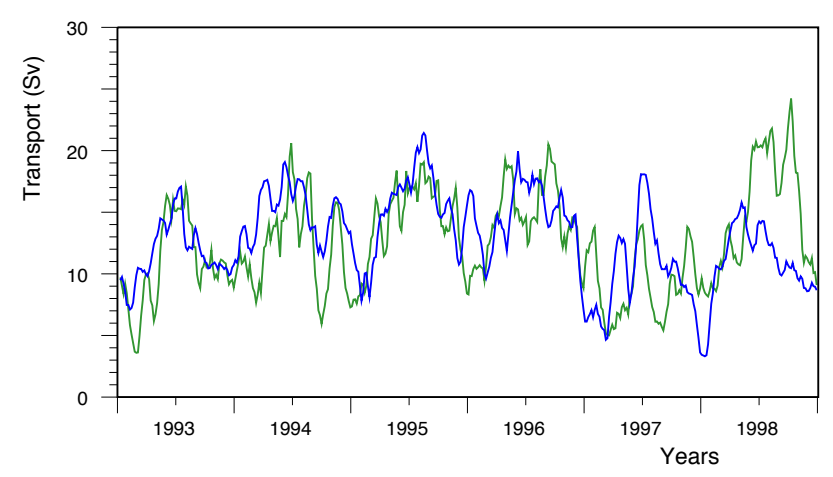

Fig. 14. Thirty-five day average of (blue) model throughflow and (green) throughflow calculated from Godfrey's Island Rule. The Pacific was affected by an El Niño in 1997 and 1998.

gate thorough the system than the normal annual variations seen earlier.

When calculating the response values, we hoped to find evidence that propagation delays were responsible for the differences between the two time series. However we could find no evidence for this, either in the analysis of individual years (Table 4) or in a combined analysis of the whole six-years.

\section{Comparison with observations}

The analysis so far has concentrated on the behaviour of the model ocean under the two forcing regimes. In this final section on the analysis, the focus is on how well the model reproduces know aspects of the real ocean. The best set of data available for the region is hydrographic data and this is considered first. There is also an important set of current meter measurements which have been used to estimate transports through some of the straits.

The comparisons show up a number of apparent failings of the model. Most seem to be the result of errors in the model physics but there are some where the model may be partially correct. In any case the results are a stimulus - both to improve the model and to improve our limited physical understanding of the flows.

\subsection{The water masses}

The Indonesian Throughflow transports an important group of water masses from the North Pacific into the Indian Ocean. Within the region, the deep basins also give rise to a series of remarkably uniform water masses. In order to illustrate how well the model represents such features, Fig. 15 shows the average summer temperatures during years nine to fourteen of the monthly climatological wind forced run along a section through the eastern side of the Indonesian Archipelago. 
Table 3. The mean value of the Indonesian Throughflow in the model, when forced by monthly climatological winds, and its amplitude at one, two and three cycles per year compared with the value predicted by Godfrey's Island Rule, during years nine to thirteen of the model run. Also shown is the ratio of the two values and the number of degrees that the model transport delays the wind contribution to the Godfrey integral. Small differences in the Godfrey term arise because the model data is archived on different days each year

\begin{tabular}{|c|c|c|c|c|c|c|c|c|}
\hline \multirow{2}{*}{ Year } & \multicolumn{2}{|c|}{ Transport (Sv) } & \multicolumn{2}{|c|}{ Response } & \multicolumn{2}{|c|}{ Transport (Sv) } & \multicolumn{2}{|c|}{ Response } \\
\hline & Model & Godfrey & Amp. & Phase & Model & Godfrey & Amp. & Phase \\
\hline & \multicolumn{4}{|c|}{ Mean } & \multicolumn{4}{|c|}{$1 \mathrm{cy} / \mathrm{yr}$} \\
\hline 9 & 12.43 & 11.64 & 1.07 & - & 2.26 & 1.98 & 1.14 & 0 \\
\hline 10 & 12.08 & 11.64 & 1.04 & - & 1.62 & 1.98 & 0.82 & 0 \\
\hline 11 & 11.62 & 11.64 & 1.00 & - & 1.80 & 1.99 & 0.90 & -10 \\
\hline 12 & 11.43 & 11.64 & 0.98 & - & 1.85 & 1.98 & 0.93 & -14 \\
\hline 13 & 11.13 & 11.64 & 0.96 & - & 1.97 & 1.98 & 1.00 & 15 \\
\hline \multirow[t]{2}{*}{14} & 11.15 & 11.64 & 0.96 & - & 2.07 & 1.99 & 1.04 & 14 \\
\hline & \multicolumn{4}{|c|}{$2 \mathrm{cy} / \mathrm{yr}$} & \multicolumn{4}{|c|}{$3 \mathrm{cy} / \mathrm{yr}$} \\
\hline 9 & 0.79 & 2.02 & 0.39 & -167 & 0.79 & 1.75 & 0.45 & -116 \\
\hline 10 & 0.43 & 2.02 & 0.21 & 126 & 0.43 & 1.75 & 0.25 & -157 \\
\hline 11 & 0.45 & 2.05 & 0.22 & 124 & 0.28 & 1.69 & 0.17 & -122 \\
\hline 12 & 0.77 & 2.01 & 0.38 & 137 & 0.48 & 1.75 & 0.27 & -83 \\
\hline 13 & 0.58 & 2.01 & 0.29 & -140 & 0.23 & 1.75 & 0.13 & -47 \\
\hline 14 & 0.44 & 2.05 & 0.21 & -111 & 0.55 & 1.69 & 0.32 & -112 \\
\hline
\end{tabular}

Table 4. The mean value of the Indonesian Throughflow in the model, when forced by ECMWF analysed six-hourly winds, and its amplitude at one, two and three cycles per year compared with the value predicted by Godfrey's Island Rule, during model years 1993 to 1998 . Also shown is the response, the ratio of the two values and the number of degrees that the model transport delays the wind contribution to the Godfrey integral.

\begin{tabular}{|c|c|c|c|c|c|c|c|c|}
\hline \multirow[t]{2}{*}{ Year } & \multicolumn{2}{|c|}{ Transport (Sv) } & \multicolumn{2}{|c|}{ Response } & \multicolumn{2}{|c|}{ Transport (Sv) } & \multicolumn{2}{|c|}{ Response } \\
\hline & Model & Godfrey & Amp. & Phase & Model & Godfrey & Amp. & Phase \\
\hline & \multicolumn{4}{|c|}{ Mean } & \multicolumn{4}{|c|}{$1 \mathrm{cy} / \mathrm{yr}$} \\
\hline 93 & 11.652 & 10.618 & 1.097 & - & 2.85 & 4.01 & 0.71 & -20 \\
\hline 94 & 14.883 & 12.332 & 1.207 & - & 1.98 & 2.51 & 0.79 & -24 \\
\hline 95 & 14.867 & 14.107 & 1.054 & - & 4.51 & 3.90 & 1.16 & 3 \\
\hline 96 & 14.686 & 14.313 & 1.026 & - & 2.58 & 2.98 & 0.86 & 8 \\
\hline 97 & 10.187 & 9.019 & 1.129 & - & 4.06 & 1.10 & 3.70 & -128 \\
\hline 98 & 10.857 & 14.946 & 0.726 & - & 3.54 & 5.95 & 0.60 & -58 \\
\hline \multirow[t]{2}{*}{$93-98$} & 12.858 & 12.561 & 1.024 & - & & & & \\
\hline & \multicolumn{4}{|c|}{$2 \mathrm{cy} / \mathrm{yr}$} & \multicolumn{4}{|c|}{$4 \mathrm{cy} / \mathrm{yr}$} \\
\hline 93 & 1.14 & 2.27 & 0.50 & -18 & 0.29 & 0.58 & 0.50 & 15 \\
\hline 94 & 1.19 & 2.34 & 0.51 & -43 & 1.48 & 1.38 & 1.07 & -22 \\
\hline 95 & 0.26 & 1.18 & 0.22 & 64 & 1.48 & 1.30 & 1.14 & 73 \\
\hline 96 & 1.05 & 2.53 & 0.41 & 135 & 0.53 & 1.61 & 0.33 & 128 \\
\hline 97 & 0.96 & 2.83 & 0.34 & 2 & 1.11 & 1.72 & 0.64 & 96 \\
\hline 98 & 1.63 & 0.53 & 3.05 & 53 & 1.14 & 1.91 & 0.59 & 74 \\
\hline
\end{tabular}

The section is similar to that used by Wyrtki (1961) in reporting observations from the region (see his Fig. 6.25, also based on summer data), and by van Aken et al. (1988) in their report on later measurements. The Levitus and Boyer (1994a) summer temperatures, plotted for the same section in Fig. 16, lie close to the values given in the two observational papers.
Comparison of the different figures shows that above $1200 \mathrm{~m}$, at the levels with the largest transports, there is reasonable agreement between the model and observations. Below $1200 \mathrm{~m}$ the flow is blocked by sills. The resulting water properties therefore reflect the actual water mass overflowing each sill and the mixing processes occurring within the sill regions and the deep basins. 


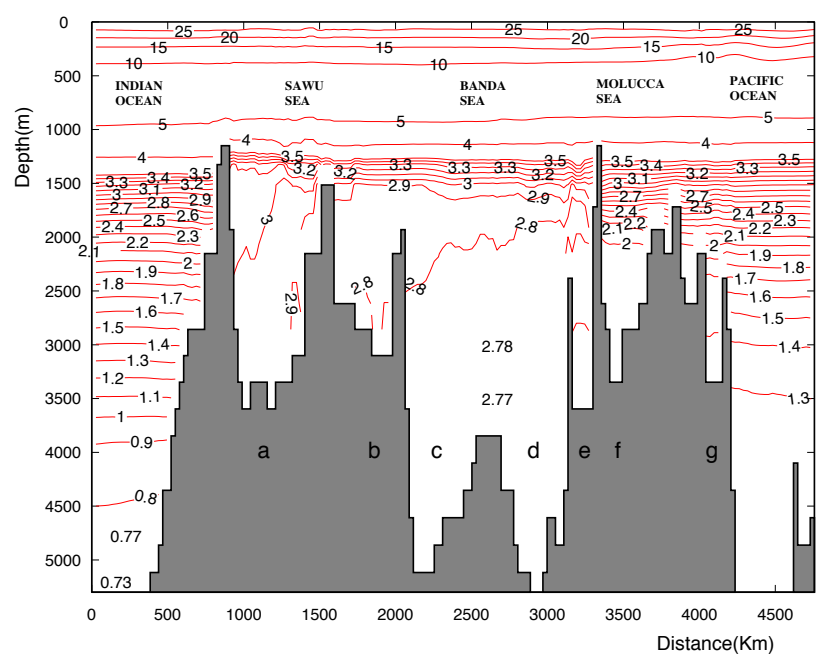

Fig. 15. Pacific to Indian Ocean section, showing model potential temperature in summer from the run with monthly wind forcing. The deep basins are (a) Sawu, (b) Wetar, (c) South Banda, (d) North Banda, (e) Buru, (f) Bacan and (g) Morotai Basin.

In the deep Pacific and Indian Oceans the model temperature profiles are little changed from the initial state and so are in reasonable agreement with observations. In the deep Indonesian Basins, the bottom temperatures in the model also compare well with observations, warming slowly in going from the Pacific to the Indian Ocean. However in the vertical, the temperature gradient is much weaker than it should be. As a result, the deep basins are capped by a much stronger thermal gradient than is observed in the real ocean.

This result was unexpected. Ocean models like OCCAM, which use level surfaces, tend to produce too much vertical mixing in the open ocean, because of numerical effects and because of internal waves which mix water up and down between model layers. These effects should mix down additional heat from the surface layers, weakening the thermocline and warming the deep basins. Mixing in the poorly represented overflows would also tend to increase the model temperatures at depth.

We investigated the Banda Sea region and concluded that the error there arose primarily because of model errors at the Lifamatola Strait $\left(1^{\circ} 10^{\prime} \mathrm{S}, 126^{\circ} 49^{\prime} \mathrm{E}\right)$. This lies at the southern end of the Molucca Sea. It is the deepest sill connecting the Banda Sea to the Pacific Ocean and is deeper than any of the routes connecting the Banda Sea with the Indian Ocean.

A detailed survey of the strait (van Aken et al., 1988), showed that the overflow region is roughly $\mathrm{V}$-shaped in profile and that it has a sill depth that lies between $1950 \mathrm{~m}$ and $2000 \mathrm{~m}$. Below $1900 \mathrm{~m}$ the strait is less than $2 \mathrm{~km}$ wide, at $1700 \mathrm{~m}$ it is approximately $5 \mathrm{~km}$ wide and at $1500 \mathrm{~m}$ approximately $20 \mathrm{~km}$ wide. Current measurements in the strait showed that the transport was $1.5 \mathrm{~Sv}$ and temperature pro-

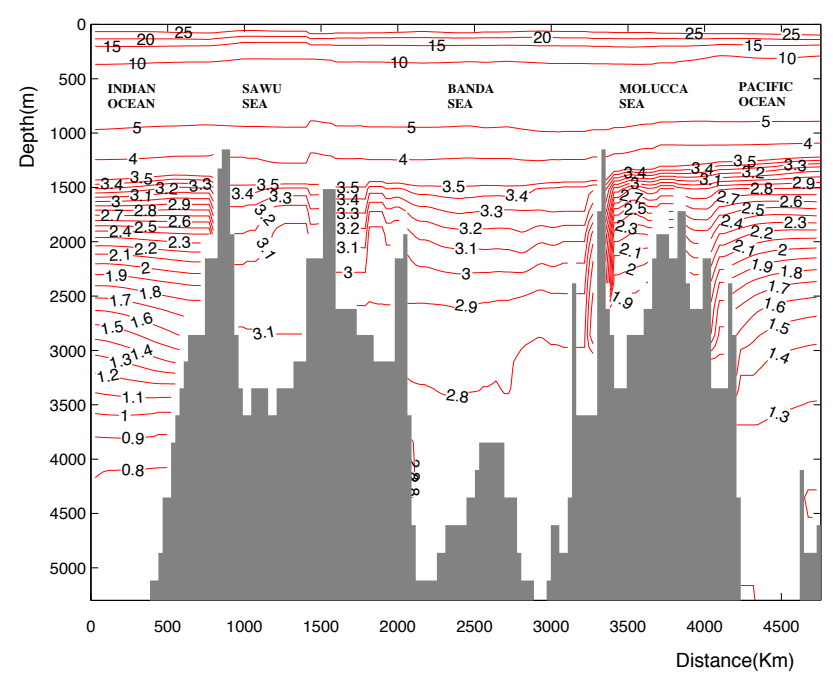

Fig. 16. Pacific to Indian Ocean section, showing in-situ potential temperature in summer from the Levitus (1994a) dataset.

files downstream showed that the overflow forms a "quasihomogeneous layer" with a thickness of about $500 \mathrm{~m}$, which continues downslope to depths near $3000 \mathrm{~m}$ (van Aken et al., 1991).

In the model, the Lifamatola Strait is represented with a sill at $1823 \mathrm{~m}$. During the analysis period all the southward flow was confined to the bottom layer (extending upwards from $1823 \mathrm{~m}$ to $1615 \mathrm{~m}$ ). The transport in the layer was $0.8 \mathrm{~Sv}$ and the temperature was approximately $2.5^{\circ} \mathrm{C}$. The transport is less that that observed but the temperature is approximately equal to the average temperature of the overflow observed by van Aken et al. (1988). It is also similar to the temperature in the offshore Pacific at this depth.

Near the sill, at a depth of $1950 \mathrm{~m}$, van Aken et al. (1988) observed temperatures of $2.3^{\circ} \mathrm{C}$ but bottom temperatures rose to $2.4^{\circ} \mathrm{C}$ only a few kilometers downstream. Further downstream, the minimum temperature in the Baru Basin is approximately $2.6^{\circ} \mathrm{C}$ and in the Banda Sea itself the minimum observed temperatures lie near $2.78^{\circ} \mathrm{C}$ (Wyrtki, 1961).

Both the observations and the model are thus consistent with the inflow of Pacific waters in a layer, possibly a few hundred metres thick, with average temperatures near $2.5^{\circ} \mathrm{C}$. There is then some turbulent mixing in the overflow which produces warmer temperatures at the bottom of the Baru Basin and the Banda Sea.

This does not explain why, during the analysis period, both the transport in the overflow and the density profile in the deep basins are so weak. However further study indicates that both effects arise because the model sill is far too wide. As the model uses a grid spacing of $1 / 4^{\circ}$, the sill has a width of one velocity grid box $(27.8) \mathrm{km}$ and two tracer grid boxes $(55.6 \mathrm{~km})$. The increased number of tracer boxes arises from the staggered grid used by the Arakawa-B scheme. As a 
result the overflow is best thought of as having a velocity profile in the horizontal which is triangular in shape, with a maximum in the centre and a width of $55.6 \mathrm{~km}$.

If we assume that the average width of the actual sill is given by the value at $1700 \mathrm{~m}$, then the model sill has a cross sectional area which is eleven times too large. During the analysis period the transport in model is low but this is only after the presure difference between the Pacific and the Banda Basin has almost equalised (it is then equivalent to a dynamic height difference of $0.25 \mathrm{~cm}$ ). During year 4 of the run, the earliest available for analysis, the transport was much higher $(3.6 \mathrm{~Sv})$. The dynamic height difference $(1.0 \mathrm{~cm})$ was also higher and presumably more realistic.

The large width of the model sill also means that the viscous terms are underestimated. The horizontal viscosity term is proportional to the width squared, so even after allowing for the excess length of the channel (two velocity boxes, so possibly a factor of three too long), the viscosity term in the model is still likely to be a factor of 40 too small. Analysis of the momentum balance in the sill regions showed that both at year 4 and during the main analysis period, the viscosity term was a factor of 10 smaller than the along channel pressure gradient ${ }^{4}$. With a realistic channel width the total transport would be reduced and the viscous term could thus become significant.

In their analysis of their results, van Aken et al. (1991) concluded that the vertical structure of the Banda Sea resulted from the balance between vertical mixing within the basin and the influx of the bottom waters by the inflow through the Lifamatola Strait. A flow of $1.5 \mathrm{~Sv}$ gives a flushing time of about 27 years, so if this is increased to $3.6 \mathrm{~Sv}$ or more, as occurred early in the model run, it would significantly affect the stratification after only a few years.

We conclude that the wide model sill resulted in a large inflow of dense water from the Pacific which filled the deep Banda Sea Basin early in the run. This produced a more uniform water mass in the deep basin. As the basin filled with denser water it also reduced the pressure gradient across the sill, reducing the inflow until the model transport was less than that observed.

In future models, a better representation of sills is required. This could be done by using a finer horizontal grid. An alternative is to use partial box widths, in the same way that partial box depths are presently used to obtain a better mean ocean topography. The channel width also affects the viscosity terms in the momentum equation. Thus the viscosity terms will also need correcting.

\subsection{Current meter observations and transports}

A further check on the model comes from transports estimated from the limited current meter data. In the north there

\footnotetext{
${ }^{4}$ The horizontal pressure gradient is balanced primarily by the inertial terms in the along-channel momentum equation. This is as expected when a control point is involved.
}

have been moorings in the Makassar Strait from December 1997 to July 1998 (Gordon et al., 1999; Susanto and Gordon, 2005) and the Lifamatola Passage overflow, at the southern end of the Molucca Sea, from January to March 1985 (van Aken et al., 1988, 1991).

In the south there have been measurements in the Lombok Strait from January 1985 to January 1986 (Murray and Arief, 1988; Murray et al., 1990; Arief and Murray, 1996), in the Timor Passage from August 1989 to September 1990 and from March 1992 to April 1993 (Cresswell et al., 1993; Molcard et al., 1994, 1996), and in the Ombai Strait from November 1995 to November 1996 (Molcard et al., 2001).

There have also been some indirect estimates of transports. Meyers (1996) used XBT sections and Fieux et al. (1996) hydrographic data from sections between Australia and Indonesia. Transports depended strongly on season and varied between 2.6 $\pm 9 \mathrm{~Sv}$ and $18 \pm 7 \mathrm{~Sv}$. Qu (2000) used hydrographic data to estimate the flow through the Luzon Strait (3 Sv), most of which will have turned south through the shallow S China Sea. Wolanski et al. (1988) studied the flow through Torres Strait and found a transport of order $0.01 \mathrm{~Sv}$.

In his review of the transport estimates, Gordon (2005) concluded that the mean value for the total transport lies in the range of 8 to $14 \mathrm{~Sv}$, his preferred value being about $10 \mathrm{~Sv}$. The OCCAM model transports reported here (11.7 Sv for run CMW and 12.9 Sv for E6W) are thus within the overall limits but on the high side of his preferred value.

If we compare individual straits the agreement is not so good. In the north the most striking difference is in the Makassar Channel, where the model gives values of 5.7 and $5.9 \mathrm{~Sv}$ for the two runs. These are lower than Susanto and Gordon's (2005) estimate of 7 to $11 \mathrm{~Sv}$. There is also a marked difference in the Halmahera Sea where the model shows transports of 1.6 and 3.4 Sv. Gordon (2005) assumed the transport here was negligible but Cresswell and Luick (2001) using a single mooring found a transport of $1.5 \mathrm{~Sv}$ at depths between $350 \mathrm{~m}$ and $700 \mathrm{~m}$. Unfortunately, in the model this channel is blocked at these depths so flow only occurs above $300 \mathrm{~m}$. However both observations and model indicate this may be a significant pathway.

Between the two straits lies the Malacca Strait with its sill at the Lifamatola Strait. van Aken et al. (1991) estimated a transport of $1.5 \mathrm{~Sv}$ in the overflow and implied that after mixing and upwelling this continued as part of the throughflow. In the model there is an overflow, as discussed in the previous section, but the upwelled water returns to the Pacific (see Fig. 15). This is because the sill to the Indian Ocean lies at a much shallower depth $(1420 \mathrm{~m})$. Above $1000 \mathrm{~m}$ the model shows a second region of inflow through the Malacca Strait which continues through to the Indian Ocean.

In the south, the most striking difference between the model and observations occurs in the Lombok Strait. Murray and Arief (1988) found a transport of of $1.7 \mathrm{~Sv}$ concentrated in the upper $200 \mathrm{~m}$. The model finds much larger values, 
$5.7 \mathrm{~Sv}$ and $5.6 \mathrm{~Sv}$ for the two runs but agrees that these are concentrated in the top $200 \mathrm{~m}$.

Further east observations in the Timor Passage (Cresswell et al., 1993; Molcard et al., 1994, 1996) give transports of 3 to $6 \mathrm{~Sv}$, the model much lower values of 1.1 and $2.1 \mathrm{~Sv}$. For the Ombai Strait, Molcard et al. (2001) estimate 4 to 6 Sv, the model 4.5 and $4.9 \mathrm{~Sv}$. The model thus seems to increasing the near surface flows in the Lombok Strait at the expense of the Timor Passage.

\subsection{The deep western channels}

In studying these discrepancies we have concentrated on the two deep western channels, the Makassar Strait where the model transport appears to be too low and the Lombok Strait where it appears to be too high. At the surface, the Makassar Strait appears to be very much wider than the Timor Strait, but it is blocked by sediments at its southern end, so that below $30 \mathrm{~m}$ the width is reduced to about $25 \mathrm{~km}$.

The Timor Strait has a similar width over most of its length, but around $115^{\circ} 45^{\prime} \mathrm{E}, 8^{\circ} 46^{\prime} \mathrm{S}$, near the island of Paula Penida, it narrows to $13 \mathrm{~km}$ for a distance of under $20 \mathrm{~km}$. As with the Lifamatola Sill, the width at the narrows is less than the model grid, so the extra model transport may be partially explained by the differing cross-sectional area at the narrowest point.

The model is also likely to be underestimating the effect of viscosity in the strait. In the model, the magnitude of the horizontal viscous forces acting on the top $200 \mathrm{~m}$ is equivalent to a pressure difference of approximately $0.4 \mathrm{~cm}$ between the ends of the strait. In comparison, the average dynamic height difference along the western boundary at this depth is $3 \mathrm{~cm}$. Thus in the model, viscosity appears to have little effect on the flow. However if it were increased by a factor of four or more, its effect should become significant. This would happen if the width of the strait was correctly represented in the model. Internal tides and other features of the flow may also increase the viscosity in the region.

The low model transport in the Makassar Strait is not so easily understood. The narrowest section, the Labani Channel $\left(3^{\circ} 0^{\prime} \mathrm{S}, 118^{\circ} 40^{\prime} \mathrm{E}\right)$ is about $28 \mathrm{~km}^{\text {wide }}{ }^{5}$ and $70 \mathrm{~km}$ long, so it is reasonably well represented by the model. The viscous terms, at year 10.0 in run CMW, correspond to a dynamic height difference of $0.6 \mathrm{~cm}$. This is much smaller than the actual difference in dynamic height between the ends of the Labani Channel ( $3 \mathrm{~cm}$ at a depth of $100 \mathrm{~m}$ ).

Both here and in the Lombok Strait, the difference is consistant with a horizontal control point acting on the surface layers of the channel. Such control points have been discussed by Armi and Williams (1993). The strong accelerations at the entrance to the channel and the shallowing of the density surfaces in passing through the channel give support

\footnotetext{
${ }^{5}$ Wajsowicz at al. (2003), Fig. 9, show that the channel is just under $50 \mathrm{~km}$ wide at their mooring position.
}

to this conclusion. If so, it is possible that the model is providing too much control on the flow in the Labani Channel. This may be due to finite-difference effects in the model but, whatever the explanation, the effect must be subtle in order to explain why similar constrictions produce too much flow in the Lombok Strait and too little in the Makassar Strait.

Having failed to explain the behaviour in terms of small scale model physics, we also looked at the larger scale. If Godfrey's theory is correct and the throughflow is primarily generated by the northward flow in the South Pacific, then the shortest route to the Indian Ocean is via the Halmahera Sea. In order to follow the "deep western boundary current" route via the Makassar Strait, the flow would have to go a few degrees further north. At mid-latitudes any blockage like this normally causes the current to split (Webb, 1993). So if Godfrey is correct, the throughflow should generate flows through both the Halmahera Sea and the Makassar Strait - as seen in the model.

\section{Discussion}

The Indonesian region has an important role in the large scale circulation of the ocean. It therefore needs to be accurately represented in many types of ocean model, ranging from the high resolution ocean physics models, to the medium resolution biological models and the low resolution ocean models used in climate change research. Over the next ten years, most ocean models are likely to use a resolution similar to or lower than the one used here. The results of the present work should thus be relevant to all such models.

The present analysis has shown a number of areas where the model agrees roughly with expectations. Rather more interesting are the areas where the model fails and areas where it throws up questions whose solution seems to require better observations and the development of better theories.

We have shown that after nine years with climatological winds, the total throughflow agrees with observations and, to within a few percent, with the value predicted by Godfrey's Island Rule. Using the more realistic ECMWF winds we found that the model and Godfrey's Island Rule roughly agree at a period of one cycle per year. They disagree at shorter periods, which one might expect, but they also give different values for the year to year variations in transport. To us it seems odd that both the long term and annual wind fields give agreement between the model and Godfrey's Island Rule but that at intermediate frequencies the agreement breaks down. The results invite further study.

One promising approach is that of Lee et al. (2001). He used an adjoint model to show that at periods of a year, the throughflow is affected by winds in the western equatorial Pacific and by winds south of Australia. Both regions lie near the path of the Godfrey Integral and so help to explain the correlation seen here. It would be interesting to use an adjoint model to investigate the relationships at other frequencies. 
When we investigated the spectra, we found that the spectra of the flows through the individual northern straits differ significantly from the spectra through the southern straits (although the spectra for the total flows are similar). Further investigation indicated that the difference was due to changes in the offshore current field which affected individual northern straits. Thus the flow through the Makassar Strait was significantly reduced when an eddy in the Celebes Sea moved close to the northern end of the strait. The flow via the Molucca Sea was similarly affected when the Halmahera Eddy (or Retroflection) extended close to its northern boundary.

In the deep basins we found that although the deep temperatures were reasonable, the vertical stratification was too weak. This was traced to errors in the sills, especially the Lifamatola Sill which was far too wide. Part of the problem could be solved by introducing partial box widths, as well as the partial bottom box depths that are used in current ocean models. However the V-shaped sill region is much more complex than is usually allowed for in ocean models and raises the question of what improvements are needed before the models can accurately represent the effect of critical points, mixing and other aspects of the overflows.

The model also raised the question of what happens to the deep water upwelled in the Banda Sea and surrounding basins. Usually it is assumed that this continues upwelling within the region until it is shallow enough to continue on into the Indian Ocean. However the model results suggest that the upwelled water returns to the Pacific. If in reality this does not happen, we need to understand why.

The model flow through the Lombok Strait was much larger than the observations. The reason is again probably due to the channel width being too large in the model. The representation of viscosity in the model and the extra effects of locally generated turbulence in the strait could also be involved. For many purposes an "engineering" fix can be used in which viscosity is increased ${ }^{6}$ or a partial box width is used. However as with the overflows it is not obvious that this will correctly represent the effect of changes in the flow. Better observations, better theories and better model parameterisations are all needed.

Finally the model gave lower transports through Makassar Strait than were expected, and larger transport through the Halmahera Sea. We are unable to explain the discrepancy although, as discussed, in both cases horizontal control points may be involved. The possibility needs to be explored further.

If the long term mean throughflow is determined by the Godfrey Island Rule then we would expect the northward flow in the S. Pacific to take the shortest route to the Indian Ocean $^{7}$. This would involve a current along the north coast

\footnotetext{
${ }^{6}$ As used in other models, (G. Madec, private communication).

${ }^{7}$ For other implications see http://www.ocean-sci-discuss.net/4/ S289/2007/.
}

of New Guinea which, on approaching Halmahera, is likely to split. Part would turn south into the Halmahera Sea and part turn north to eventually join the Makassar Strait current.

It is possible that this is what happens. If so then the observations of Cresswell and Luick (2001) may be significant but why are the Makassar transport estimates so large? If the theory is not correct then why not? In either case some key part of the observations or the theory appears to be missing. Further research is required.

Acknowledgements. We wish to thank Beverly de Cuevas and Andrew Coward for their valuable work with the OCCAM model and for their technical support and helpful comments during the period of this research.

Edited by: K. Döös

\section{References}

Arakawa, A.: Computational design for long-term numerical integration of the equations of fluid motion: Two-dimensional incompressible flow, J. Comput. Phys., 1, 119-143, 1966.

Arief, D. and Murray, S. P: Low-frequency fluctuations in the Indonesian Throughflow through Lombok Strait, J. Geophys. Res., 101(C5), 12 455-12 464, 1996.

Armi, L. and Williams, R.: The hydraulics of a stratified fluid flowing through a contraction, J. Fluid Mech., 251, 355-375, 1993.

Bryan, K.: A numerical method for the study of the circulation of the world ocean, J. Comput. Phys., 4, 347-376, 1969.

Bryden, H. L. and Beal, L. M.: Role of the Agulhas current in Indian ocean circulation and associated heat and freshwater fluxes, Deep-Sea Res., 48, 1821-1845, 2001.

Cox, M. D.: A primitive equation 3-dimensional model of the ocean. Tech.Rep. 1, Geophysical Fluid Dyn. Lab, Natl. Oceanic and Atmos. Admin., Princeton Uni. Press, Princeton, N.J., 1984.

Cresswell, G., Frische, A., Peterson J., and Quadfasel, D.: Circulation in the Timor Sea, J. Geophys. Res., 98, 14379-14389, 1993.

Cresswell, G. R. and Luick J. L.: Current measurements in the Halmahera sea, J. Geophys. Res., 106, 13 945-13 951, 2001.

Fieux, M., Molcard, R., and Ilahude, A. G.: Geostrophic transport of the Pacific-Indian Ocean throughflow, J. Geophys. Res., 101(C5), 12 421-12 432, 1996.

Godfrey, J. S.: A Sverdrup model of the depth-integrated flow for the world ocean allowing for Island circulations, Geophys. Astro. Fluid, 45, 89-112, 1989.

Godfrey, J. S.: The effect of the Indonesian Throughflow on ocean circulation and heat exchange with the atmosphere: A review, J. Geophys. Res., 101(C5), 12 217-12 237, 1996.

Gordon, A. L.: Oceanography of the Indonesian Seas and their Throughflow, Oceanography, 18(4), 14-27, 2005.

Gordon, A. L., Susanto, R. D., and Ffield, A.: Throughflow within Makassar Strait, Geophys. Res. Lett., 26, 3325-3328, 1999.

Griffies, S. M., Gnanadesikan, A., Dixon, K. W., Dunne, J. P., Gerdes, R., Harrison, M. J., Rosati, A., Russell, J. L., Samuels, B. L., Spelman, M. J., Winton, M., and Zhang, R.: Formulation of an ocean model for global climate simulations, Ocean Sci., 1, 
45-79, 2005,

http://www.ocean-sci.net/1/45/2005/.

Hellerman, S. and Rosenstein, M.: Normal monthly wind stress over the world ocean with error estimates, J. Phys. Oceanogr., 13, 1093-1104, 1983.

Lee, T., Giering, R., and Cheng, B.: Adjoint sensitivity of Indonesian throughflow transport to wind stress: application to interannual variability, Jet Propulsion Laboratory Publication 01-11, 36 pp., 2001.

Levitus, S.: Climatological atlas of the world ocean, NOAA Professional Paper No. 13, GFDL, Princeton University, NJ, 1982.

Levitus, S. and Boyer, T. P.: World Ocean Atlas 1994, NOAA Atlas NESDIS, Vol. 4, Temperature, 117 pp., 1994a.

Levitus, S., Burgett, R., and Boyer, T. P.: World Ocean Atlas 1994, NOAA Atlas NESDIS, Vol. 3, Salinity, 99 pp., 1994 b.

Molcard, R., Ilahude, A. G., Fieux, M., Swallow, J. C., and Banjarnahor, J.: Low frequency variability of the currents in Indonesian Channels (Savu-Roti M1 and Roti-Ashmore Reef M2), Deep Sea Res., 41, 1643-1662, 1994.

Molcard, R., Fieux, M., and Ilahude, A. G.: The Indo-Pacific Throughflow in the Timor Passage, J. Geophys. Res., 101, 12411-12 420, 1996.

Molcard, R., Fieux, M., and Syamsudin, F.: The Throughflow within Ombai strait, Deep-Sea Res., 48(5), 1237-1253, 2001.

Murray, S. P. and Arief, D.: Throughflow into the Indian Ocean through the Lombok Strait, January 1985-January 1986, Nature, 333, 444-447, 1988.

Murray, S. P., Arief, D., Kindle, J. C., and Hurlburt, H. E.: Characteristics of circulation in an Indonesian Archipelago Strait from hydrography, current measurements and modelling results, in: The Physical Oceanography of Sea Straits, edited by: Pratt, L., Kluwer Academic Publishers, Norwell, MA, 3-23, 1990.

Meyers, G.: Variation of Indonesian throughflow and the El NiñoSouthern Oscillation, J. Geophys. Res., 101, 12 255-12 263, 1996.

Pacanowski, R. C. and Philander, S. G. H.: Parameterization of vertical mixing in numerical models of tropical oceans, J. Phys. Oceanogr., 11, 1443-1051, 1981.

Pirani, A.: Testing Godfrey's Island Rule using the OCCAM model for the calculation of the Indonesian Throughflow, MSc Thesis, University of Southampton, 1999.

Qu, Tangdong: Upper-Layer Circulation in the South China Sea, J. Phys. Oceanogr., 30, 1450-1460, 2000.

Qu, Tangdong, Yan, Du, Meyers, G., Ishida, Akio, and Wang Dongxiao: Connecting the tropical Pacific with Indian Ocean through South China Sea. Geophys. Res. Lett., 32, L24609, doi:10.1029/2005GL024698, 2005.

Semtner, A. J.: An oceanic general circulation model with bottom topography. Technical Report No. 9, Dept. of Meteorology, UCLA, Los Angeles, CA 90095, 1974.
Siefridt, L. and Barnier, B.: Banque de Donnes AVIS Vent/flux: Climatologie des Analyses de Surface du CEPMMT, ORSTOM Report 911430 025, Toulouse, 1993.

Susanto, R. D. and Gordon, A. L.: Velocity and transport of the Makassar Strait throughflow, J. Geophys. Res., 110, C01005, doi:10.1029/2004JC002425, 2005.

Thompson, S. R.: Sills of the global ocean: a compilation, Ocean Model., 109, 7-9, 1995.

Tozuka, Tomoki, Qu, Tangdong, and Yamagata, Toshio: Dramatic impact of the South China Sea on the Indonesian Throughflow, Geophys. Res. Lett., 34, L12612, doi:10.1029/2007GL030420, 2007.

U.S. Naval Oceanographic Office and the U.S. Naval Ocean Research and Development Activity: DBDB5 (Digital Bathymetric Data Base-5 Minute Grid), U.S.N.O.O., Bay St. Louis, 1983.

van Aken, H. M., Punjanan, J., and Saimima, S.: Physical aspects of the flushing of the East Indonesian basins, Neth. J. Sea Res., 22, 315-339, 1988.

van Aken, H. M., Van Bennekom, A. J., Mook, W. G., and Postma, H.: Application of Munks abyssal recipes to tracer distributions in the deep waters of the southern Banda basin, Oceanologica Acta, 14(2), 151-162, 1991.

Wajsowicz, R. C.: The circulation of the depth-integrated flow around an island with application to the Indonesian Throughflow, J. Phys. Oceanogr., 23, 1470-1484, 1993.

Wajsowicz, R. C., Gordon, A. L., Ffield, A., and Susanto, R. D.: Estimating Transport in Makasar Strait, Deep-Sea Res. II, 50, 2163-2181, 2003.

Webb, D. J.: A simple model of the effect of the Kerguelen Plateau on the strength of the Antarctic Circumpolar Current, Geophys. Astro. Fluid, 70, 57-84, 1993.

Webb, D. J.: The vertical advection of momentum in Bryan-CoxSemtner ocean general circulation models, J. Phys. Oceanogr., 25(12), 3186-3195, 1995.

Webb, D. J., de Cuevas, B., and Richmond, C.: Improved advection schemes for ocean models, J. Atmos. Ocean. Tech., 15, 11711187, 1998a.

Webb, D. J., de Cuevas, B. A., and Coward, A. C.: The first main run of the OCCAM global ocean model, Internal Report of James Rennell Divesion, Southampton Oceanography Centre, UK., 1998b.

Wolanski, E., Ridd, P., and Inoue, M.: Currents through Torres Strait, J. Phys. Oceanogr., 18, 1535-1545, 1988.

Wyrtki, K.: NAGA Report, Vol. 2, Scientific results of marine investigations of the South China sea and the Gulf of Thailand 1959-1961, Physical Oceanography of the Southeast Asian Water, Scripps Institution of Oceanography, 195 pp., 1961. 